\title{
Occurrence of Tocols in Foods: An Updated Shot of Current Databases
}

\author{
Alessandra Durazzo ${ }^{D},{ }^{1}$ Amirhossein Nazhand, ${ }^{2}$ Massimo Lucarini ${ }^{(D)}, 1$ \\ Amélia M. Delgado $\mathbb{D},{ }^{3}$ Maryna De Wit $\mathbb{D},{ }^{4}$ Kar Lin Nyam, ${ }^{5}$ Antonello Santini $\mathbb{D}^{6}{ }^{6}$ \\ and Mohamed Fawzy Ramadan $\mathbb{D}^{7,8}$ \\ ${ }^{1}$ CREA-Research Centre for Food and Nutrition, Via Ardeatina 546, Roma 00178, Italy \\ ${ }^{2}$ Department of Biotechnology, Sari Agricultural Science and Natural Resource University, Sari 48181 68984, \\ 9th $\mathrm{km}$ of Farah Abad Road, Mazandaran, Iran \\ ${ }^{3}$ Mediterranean Institute for Agriculture, Environment and Development, Universidade do Algarve, Edf 8, Campus de Gambelas, \\ 8005-139 Faro, Portugal \\ ${ }^{4}$ Department of Sustainable Food Systems and Extention, University of the Free State, Bloemfontein, South Africa \\ ${ }^{5}$ Department of Food Science with Nutritio, Faculty of Applied Sciences, UCSI University, 56000 Kuala Lumpur, Malaysia \\ ${ }^{6}$ Department of Pharmacy, University of Napoli Federico II, Via D. Montesano 49, Napoli 80131, Italy \\ ${ }^{7}$ Agricultural Biochemistry Department, Faculty of Agriculture, Zagazig University, Zagazig 44519, Egypt \\ ${ }^{8}$ Deanship of Scientific Research, Umm Al-Qura University, Makkah, USA \\ Correspondence should be addressed to Alessandra Durazzo; alessandra.durazzo@crea.gov.it
}

Received 27 August 2020; Revised 11 January 2021; Accepted 13 January 2021; Published 12 February 2021

Academic Editor: Constantin Apetrei

Copyright (C) 2021 Alessandra Durazzo et al. This is an open access article distributed under the Creative Commons Attribution License, which permits unrestricted use, distribution, and reproduction in any medium, provided the original work is properly cited.

\begin{abstract}
Tocols are present in various foods, mostly in fruits and in plant seeds. Edible oils are the most important natural dietary sources of tocopherols and tocotrienols, collectively known as tocols. Tocopherols and tocotrienols are considered beneficial for their antioxidant effect which impacts on prevention of different health conditions. This perspective is addressed to give an updated picture of the tocol occurrence in foods. Moreover, the current state of the art of tocols in updated databases is explored and commented outlining their importance and future trends.
\end{abstract}

\section{Introduction}

Tocols (tocopherols and tocotrienols), as shown in Figure 1, are monophenols obtained from 6-hydroxy-2-methyl-2phytylchroman, which are applied as food additives in the food and pharmaceutical industries [1]. Some of the chemical characteristics of the tocols include their solubility in polyethylene glycol, propylene glycol, chloroform, acetone, surfactants, oils, and ethanol. They are not water soluble, while they are resistant to heat, and acid-stable, although they are instable when exposed to alkali, light, and oxygen [2].

The chemical structure of tocopherols and tocotrienols is different so that tocopherols $(\alpha, \beta, \gamma$, and $\delta)$ contain a chromanol ring and a 16-carbon phytyl side chain in their structure with methylation at three positions of 5,7 , and 8 in the chromanol ring of the $\alpha$-tocopherols, at two positions of 7 and 8 in the chromanol ring of the $\gamma$-tocopherols, and the positions of 8 in the chromanol ring of the $\delta$-tocopherols. Simultaneously, the same substitution of methyl groups can be seen in the tocotrienols on the chromanol ring with unsaturation in the 16-carbon side chain having double bonds at the positions of $3^{\prime}-, 7^{\prime}-$, and $11^{\prime}$ [3].

There are reports on different functional features of tocopherols and tocotrienols, including anticancer [4], antiobesity [5], antidiabetic [6], and cardioprotective [7] effects. Moreover, the functions of tocotrienols and tocopherols are different, and a recent study indicated a more effective activity of the tocotrienols than that of the 
<smiles>Cc1c(C)c2c(c(C)c1O)O[C@@](C)(CCCC(C)CCCC(C)CCCC(C)C)CC2</smiles><smiles>Cc1c(O)ccc2c1CC[C@@](C)(CCCC(C)CCCC(C)CCCC(C)C)O2</smiles><smiles>CC(C)=CCC/C(C)=C/CC/C(C)=C/CC[C@]1(C)CCc2c(C)c(O)c(C)c(C)c2O1</smiles><smiles>CC(C)=CCC/C(C)=C/CC/C(C)=C/CC[C@]1(C)CCc2c(C)c(O)cc(C)c2O1</smiles><smiles>CC(C)=CCC/C(C)=C/CC/C(C)=C/CC[C@]1(C)CCc2cc(O)ccc2O1</smiles><smiles>CC(C)=CCC/C(C)=C/CC/C(C)=C/CC[C@]1(C)CCc2cc(O)c(C)c(C)c2O1</smiles><smiles>CC(C)=CCC/C(C)=C/CC/C(C)=C/CC[C@]1(C)CCc2cc(O)c(C)c(C)c2O1</smiles><smiles>CC(C)=CCC/C(C)=C/CC/C(C)=C/CC[C@]1(C)CCc2cc(O)c(C)c(C)c2O1</smiles>

FIgURE 1: Structure of main tocols.

$\alpha$-tocopherol in the control of chronic disorders [8]. The results of a review article on noncommunicable diseases revealed the inhibition of hormonal changes, oxidative stress, inflammatory response, and 3-hydroxy-3-methylglutaryl-coenzyme A reductase following the administration of tocotrienols, wherein the efficiency of tocotrienols was higher than that of tocopherol. The tocotrienols alone had a better influence on the treatment of diseases rather than the combination of tocotrienols and tocopherol [9]. Idriss et al. [10] found an in vitro anticancer activity for beta-tocotrienol, which was related to the induction of p53-independent apoptosis and the stop of the cell cycle G1 phase, and a higher anti-tumorigenic potential for beta-tocotrienol when compared with gamma-tocotrienol was also noted. The administration of tocotrienol-rich fraction $(200 \mathrm{mg} / \mathrm{kg})$ for about three months showed a positive impact on the myocardial antioxidative system in rats via new GSH synthesis [11]. The administration of gamma-tocotrienol reduced adipose tissue macrophages' recruitment and systemic and adipose inflammation in mice after a month, confirming the antiobesity activity [12].

A study aimed to investigate pharmacokinetics' impact of $\delta$-tocotrienol at different high concentrations $(750-1000 \mathrm{mg} /$ d), the results of which showed Tmax value of 3-4 hours for all the isomers of tocotrienols and tocopherols, apart from $\alpha$-tocopherol. According to this finding, it can be concluded that such high concentrations of tocotrienols are safe for human use especially as therapeutic agents in the management of some disorders, e.g., Alzheimer's disease, diabetes, and cancer [13]. Liang et al. produced $\alpha$-tocopherol succinate modified chitosan (CS-TOS) and then encapsulated it using paclitaxel (PTX) to obtain micelles [14]. They could improve the performance and safety of PTX-loaded CS-TOS micelles via prolonged systemic circulation time and slow down the elimination rate than those of Taxol formulation. Based on the results from an in vivo study, the U14 tumor growth was significantly inhibited by PTX-loaded polymeric micelles, mitigating the toxicity of formulation [14].

\section{Distribution of Tocols in Foods: Occurrence}

Tocols are present in various foods, predominantly in fruits and plant seeds (see Table 1). Bastías-Montes et al. conducted a study to identify the tocols using the HPLC technique and reported the presence of $\beta$-sitosterol, tocotrienols, and $\alpha, \beta, \gamma$, and $\delta$-tocopherols from seed oil of Maqui berry (Aristotelia chilensis) fruit [15]. In a study, the two methods of direct injection and solid-phase microextraction (SPME) were combined with gas chromatography-mass spectrometry (GC-MS). The results detected $\alpha$-tocopherol $\left(\mathrm{LOD}=0.001 \mu \mathrm{g} \mathrm{mL} \mathrm{mL}^{-1}\right.$ and $\mathrm{LOQ}=0.004 \mu \mathrm{g}$ $\left.\mathrm{mL}^{-1}\right)$ and $\alpha$-tocopheryl acetate (LOD $=0.002 \mu \mathrm{g} \mathrm{mL}^{-1}$ and $\mathrm{LOQ}=0.006 \mu \mathrm{g} \mathrm{mL} \mathrm{m}^{-1}$ ), as well as the relative standard derivation (RSD) percent on days 4.8 and 8.8 in vegetables such as curly kale, celery, carrot, and onion [16]. The tocopherols were detected in vegetable oils using a novel flowthrough column electrolytic cell for supercritical fluid chromatography system, the results of which reported 3.55 RSD percent [17]. Mezni et al. found $\alpha$ - and $\gamma$-tocopherols at the concentrations of $119 \mathrm{mg} / \mathrm{kg}$ and $23 \mathrm{mg} / \mathrm{kg}$ of oil, respectively, using HPLC analysis [18]. In a recent study, the yield of edible oil was $8.6 \pm 1.2 \mathrm{~g}$ oil $/ 100 \mathrm{~g}$ of guava seeds by supercritical $\mathrm{CO}_{2}$ extraction, and then the $\gamma$-tocopherol with a concentration of $82.6 \pm 3.7 \mathrm{mg} / 100 \mathrm{~g}$ oil was detected by the GC-MS method [19]. One of the most important products derived from fruit is Hass avocado (Persea americana Mill.) 
TABLE 1: Levels of tocols in different foodstuff.

\begin{tabular}{|c|c|c|c|}
\hline & Compound & Content & Reference \\
\hline \multicolumn{4}{|l|}{ Raw foods } \\
\hline Macauba fruits & $\alpha$-Tocopherol & $4373 \mu \mathrm{g} / 100 \mathrm{~g}$ & [29] \\
\hline Cauliflower & $\alpha$-Tocopherol and $\gamma$-tocopherol & $23.47 \mathrm{mg} / 100 \mathrm{~g}$ and $74.55 \mathrm{mg} / 100 \mathrm{~g}$ & {$[30]$} \\
\hline Yellow passion fruit (Passiflora edulis) & $\gamma$-Tocopherol & $0.045 \mathrm{mg} / 100 \mathrm{~g}$ & {$[31]$} \\
\hline Broccoli & Tocopherols & $286 \mu \mathrm{g} / \mathrm{g}$ & {$[21]$} \\
\hline $\begin{array}{l}\text { Pitaya, jackfruit, durians, mango, and } \\
\text { papaya fruits }\end{array}$ & $\alpha$-Tocopherol & $0.45,0.20,0.36,0.16$, and $0.26 \mathrm{mg} / 100 \mathrm{~g} \mathrm{DW}$ & {$[32]$} \\
\hline $\begin{array}{l}\text { Oat, corn, spelt, buckwheat, wheat, rye, } \\
\text { and rice bran }\end{array}$ & Total tocochromanol & $\begin{array}{c}5.5,16.2,15.8,14.7,12.8,10.7 \text {, and } 9.1 \mathrm{mg} / \\
100 \mathrm{~g} \mathrm{DW}\end{array}$ & {$[33]$} \\
\hline Annatto seeds & $\gamma$-Tocotrienol, total tocotrienols & 3.7 and $28.9 \mathrm{~g} / 100 \mathrm{~g}$ extract & {$[34]$} \\
\hline Barely grain & $\begin{array}{l}\alpha \text {-Tocotrienol, } \gamma \text {-tocotrienol, } \\
\alpha \text {-tocopherol, and } \gamma \text {-tocopherol }\end{array}$ & $16.26,4.67,7.14,0.55 \mathrm{mg} / 100 \mathrm{~g} \mathrm{DW}$ & {$[35]$} \\
\hline $\begin{array}{l}\text { Einkorn wheat (Triticum monococcum } \\
\text { ssp. monococcum L.) }\end{array}$ & $\alpha$ - and $\beta$-tocopherol and tocotrienol & $\begin{array}{c}12.2 \mathrm{mg} / \mathrm{g} \mathrm{dm}, 4.79 \mathrm{mg} / \mathrm{g} \mathrm{dm}, 12.7 \mathrm{mg} / \mathrm{g} \mathrm{dm}, \\
\text { and } 48.2 \mathrm{mg} / \mathrm{g} \mathrm{dm}\end{array}$ & {$[36]$} \\
\hline Sesamum angustifolium & Tocopherol & $7.34 \mathrm{mg} \alpha-\mathrm{TE} / 100 \mathrm{~g}$ & {$[37]$} \\
\hline Hazelnuts & Tocols & $41.9 \mathrm{mg} / 100 \mathrm{~g}$ & {$[38]$} \\
\hline Barley genotypes (Hordeum vulgare L.) & Total tocols & 39.9 and $81.6 \mu \mathrm{g} / \mathrm{g}$ & [39] \\
\hline Irish barley & $\alpha$-Tocotrienol & $46-58 \mu \mathrm{g} / \mathrm{g} \mathrm{dw}$ & {$[40]$} \\
\hline Fresh goji berries & $\alpha$-Tocopherol and $\beta$-tocopherol & 1.4 and $1.0 \mathrm{mg} / 100 \mathrm{~g}$ & {$[41]$} \\
\hline \multicolumn{4}{|l|}{ Oils } \\
\hline Sea buckthorn berries pulp oil & Total tocols & $666-1788 \mathrm{mg} / \mathrm{kg}$ & {$[42]$} \\
\hline $\begin{array}{l}\text { Cold-pressed Moringa oleifera and } \\
\text { Moringa peregrina seed oils }\end{array}$ & $\alpha$-Tocopherol & 139.61 and $137.89 \mathrm{mg} / \mathrm{kg}$ & {$[43]$} \\
\hline Cane berry seed oils & Total tocopherols & $75-290 \mathrm{mg} / 100 \mathrm{~g}$ & {$[44]$} \\
\hline $\begin{array}{l}\text { Apple, Japanese quince, and sea } \\
\text { buckthorn seed oils }\end{array}$ & $\alpha$-Tocopherol & $58.77,121.79$, and $198.94 \mathrm{mg} / 100 \mathrm{~g}$ & {$[45]$} \\
\hline $\begin{array}{l}\text { Rapeseed, sunflower seed, linseed, } \\
\text { sesame, and maize oils }\end{array}$ & $\begin{array}{c}\alpha \text {-Tocopherol, } \beta \text {-tocopherol, } \\
\gamma \text {-tocopherol, and } \delta \text {-tocopherol }\end{array}$ & $0.6-46.1 \mathrm{mg} / 100 \mathrm{~g}$ & {$[46]$} \\
\hline $\begin{array}{l}\text { Cold-pressed pumpkin seed (Cucurbita } \\
\text { pepo L.) oil }\end{array}$ & Tocopherol and tocotrienol & $94.29-97.79 \mathrm{mg} / 100 \mathrm{~g}$ & {$[47]$} \\
\hline Soybean, corn, olive, and camellia oils & Total tocopherols & $\begin{array}{c}39.9 \mathrm{mg} / 100 \mathrm{~g}, 36.06 \mathrm{mg} / 100 \mathrm{~g}, 29.42 \mathrm{mg} / 100 \\
\mathrm{~g} \text {, and } 17.72 \mathrm{mg} / 100 \mathrm{~g}\end{array}$ & [48] \\
\hline $\begin{array}{l}\text { Sunflower, soybean, corn, hazelnut, } \\
\text { peanut, and canola oils }\end{array}$ & Total tocols & $488.88-913.51 \mathrm{mg} / \mathrm{kg}$ & [49] \\
\hline
\end{tabular}

oil, which has a great market value and is the richest source of tocopherols. Accordingly, Santana et al. extracted Hass avocado oil from dried fruit using conventional methods and then identified the $\alpha$-tocopherol with the concentration of $11.6-21.0 \mathrm{mg} / 100 \mathrm{~g}$ using normal phase HPLC with a photondiode array detector (PDA) [20]. In another study, the analytical method of LC-APCI-MS/MS was used to detect the main compounds in 12 vegetables from the Brassicaceae family, the results of which reported total levels ranging from 1.83 to $286 \mu \mathrm{g} / \mathrm{g}$ DW for tocopherols [21]. Niro et al. employed the HPLC method to detect the tocols (tocopherols and tocotrienols) in the cereals [22]. According to the findings, total levels of tocols were $3.80 \mathrm{mg} / 100 \mathrm{~g} \mathrm{~d} . \mathrm{w}$. in millet, $3.09 \mathrm{mg} /$ $100 \mathrm{~g}$ d.w. in sorghum, $5.99 \mathrm{mg} / 100 \mathrm{~g}$ d.w. in tef, $0.36 \mathrm{mg} / 100 \mathrm{~g}$ d.w. in wild rice, $9.10 \mathrm{mg} / 100 \mathrm{~g}$ d.w. in quinoa (white and pigmented), $18.06 \mathrm{mg} / 100 \mathrm{~g}$ d.w. in cañihua, $6.31 \mathrm{mg} / 100 \mathrm{~g}$ d.w. in amaranth, and $14.43 \mathrm{mg} / 100 \mathrm{~g}$ d.w. in chia. Labuschagne et al. used the HPLC method and reported the maximum tocol level of $59.8 \mathrm{mg} \mathrm{kg}^{-1}$ in the whole flour of South Africa's wheat [23]. Dạbrowski et al. applied the HPLCFLD technique to detect tocols such as $\beta / \gamma$-tocopherols in flaxseed oils using $n$-hexane $(1 \%, \mathrm{~m} / \mathrm{V})$ and isopropanol $(0.7 \%)$ solutions [24]. Bertolín et al. [25] implemented a fast, accurate, and simple method to determine carotenoids, tocopherols, retinol, and cholesterol in ovine lyophilised meat, liver, and milk and raw samples using the UHPLC method. Another recent study developed a UHPLC-LTQ-OrbitrapHRMS-based method to determine the nutrients in rice; as a result, 21 nutrients have been identified and reported in less than $13 \mathrm{~min}$ [26]. The range of regression coefficients was between 0.05 and $10 \mu \mathrm{g} / \mathrm{mL}$ for tocopherols, tocotrienols, and $\beta$-carotene, between 0.1 and $50 \mu \mathrm{g} / \mathrm{mL}$ for phospholipids, and between 0.001 and $10 \mu \mathrm{g} / \mathrm{mL}$ for $\gamma$-oryzanols. Besides, the limit of detection was between 0.2 , and $1.9 \mathrm{ng} / \mathrm{mL}$, the limit of quantitation was between 0.7 and $6.3 \mathrm{ng} / \mathrm{mL}$, the relative standard deviations were between 2.3 and $9.6 \%$, and the recoveries were between 80.6 and $109.6 \%$ for all the analytes. Moreover, the total ion current fingerprint profile showed significant differences between the brown and white rice samples. The developed method provided a convenient analytical method to identify the nutrients in rice, confirming the effectiveness of this approach for food testing [26]. 
Knecht et al. [27] developed and validated an HPLC-FLD method for tocochromanol (tocopherols and tocotrienols) analysis equally suitable for raw and cooked vegetables. The recent study of $\mathrm{Wu}$ et al. [28], reported the integrated analysis of fatty acid, sterol, and tocopherol components of seed oils obtained from four varieties of industrial and environmental protection crops, i.e., Amygdalus pedunculata Pall. (Amygdalus), Elaeagnus mollis Diels (Elaeagnus), Xanthoceras sorbifolium Bunge (Yellowhorn), and Paeonia suffruticosa Andr. (Paeonia); particularly, three tocopherol homologues, $\alpha$-, $\gamma$-, and $\delta$-tocopherols, were present in four varieties of seed oils, and Elaeagnus oil contains the highest $\alpha$-tocopherol $(7.48 \mathrm{mg} / 100 \mathrm{~g})$ and $\gamma$-tocopherol $(109.58 \mathrm{mg} /$ $100 \mathrm{~g})$ content [28].

A shot of the occurrence of tocols in different foodstuffs is given in Table 1, taking into account both more and less rich sources and more and less consumed foods.

The occurrence of tocols in food groups is described here. It is worth mentioning that the reviews [50-54] summarized common and emerging dietary sources of tocols, with particular attention to oils as the major natural dietary sources of tocopherols and tocotrienols, as well as main analytical methods and effects in food and biological systems.

\section{Tocols and Databases: The Current State of the Art}

Nowadays, the need of the categorization of bioactive compounds is emerging. A bioactive compound can be defined as a "compound that occurs in nature, part of the food chain, that can interact with one or more compounds of the living tissue, by showing an effect on human health" as reported by Biesalski et al. [55]. Databases can be viewed as a system that can generate and collect any data, information, and documentation especially organized for a rapid search and retrieval by using a computer (Encyclopaedia Britannica) [56]. They represent tools developed to simplify the storage, retrieval, modification, and deletion of data, all this in combination with several data-processing operations [57].

The development of specialized databases of components with nutritional and nutraceutical properties [58], at a National and European level, represents a current challenge to explore better the relationship between food, nutrition, health, and environment. Researches on the relationship between diet and health have led to a great interest in all bioactive substances present with the nutrients in food, and data on these and other compounds are increasingly required in the database system. Specialized databases could be useful for planning and evaluating clinical and epidemiological research studies on biologically active food contained compounds. They may represent a crucial tool to evaluate exposure measurement and, indeed, understanding the potential benefits of substances and extracts with nutritional and nutraceutical properties [59-62]. In the formulation of complete and comprehensive harmonized databases, possible limitations, as highlighted by Scalbert et al. [63], could be given both by the diversity of the chemical features of the compounds, the numerous dietary sources, the variability in content from a source to another, and by the different extraction procedures as well as the analytical techniques and methodologies used. Moreover, additional factors that should be considered in some cases are as follows: (i) only a few compounds within a class are investigated in literature studies and (ii) there is a lack of appropriate analytical methods.

As an example, as reported by the NDA Panel of the European Food Safety Authority (EFSA) in 2015 [64], the most of food composition databases in EU countries contain values for vitamin $\mathrm{E}$ as $\alpha$-tocopherol equivalents ( $\alpha$-TEs), and only two countries (Finland and Sweden) considered in the intake assessment by EFSA have vitamin E values in their food composition databases as $\alpha$-tocopherol values. Food Explorer, an innovative interface for finding food composition data, allows to simultaneously search information from most of the available databases from the European Union (EU) Member States, as well as Canada, United States, New Zealand, and Japan. Searching, for example, "Vitamin E" and selecting all the 39 databases, 398 records can be retrieved $[65,66]$.

The eBASIS database $[67,68]$ contains composition data and biological effects of over 300 major European plantderived foods organized in 24 classes of compounds (i.e., glucosinolates, polyphenols, isoflavones phytosterols, glycoalkaloids, and xanthine alkaloids).

The EuroFIR eBASIS (Bioactive Substances in Food Information Systems) is an Internet-deployed food composition and biological effects resource based on a compilation work of experts that critically evaluated data extracted from peer-reviewed literature as raw data. eBASIS could be considered as the first EU-harmonized food composition database. Concerning tocols, in eBASIS, 4 data points are present for $\alpha$-tocopherols [69].

Tocols represent essential ingredients in many dietary supplements. Nowadays, a great attention is given to the use of natural substances in different fields such as nutraceutical and cosmeceutical ones [70-72].

Recently, information on the compositions reported on labels of selected dietary supplements has been collected for the development of a Dietary Supplement Label Database according to products' availability on the Italian market, including also items consumed in the last Italian Dietary Survey [73]. Five hundred and fifty-eight products were entered into the aforementioned database, giving a homogeneous picture of the major classes of food supplements consumed in Italy. It is worth underlining that, for each item, a code was assigned following the food classification system FoodEx2 developed by EFSA [74], a tool for the standardization and harmonization of the data among different countries to guarantee interoperability between different databases [75].

In particular, in Italian Dietary Supplement Label Database, tocols are present as ingredients in different categories of products containing vitamin $\mathrm{E}$ and, in particular, as main ingredients in vitamin only supplements [A03SL], combination of vitamin and mineral only supplements [A03SN], mixed supplements/formulations [A03TC], or as minor ingredients in formulations containing special fatty acids (e.g., omega-3 and 
essential fatty acids) [A03SX], protein and amino acid supplement [A03SY], and micronutrient supplement for sports people [A03SB] [73]. The ingredient vitamin $\mathrm{E}$ was indicated using the facet [F04.A0EXL]. The code in square brackets identify the category of products.

Moving towards the scenario of metabolic pathways and the benefits of bioactive compounds in humans, Human Metabolome Database (HMDB) has been considered, in particular, the version $4.0[76,77]$. It is a freely available electronic database of information regarding small molecule metabolites found in the human body. It well linked chemical data, clinical data, and molecular biology/biochemistry data. In the above database, for instance, the following information is reported including metabocard for $\alpha$-tocopherol

(https://hmdb.ca/metabolites/ HMDB0001893) and $\beta$-tocopherol (https://hmdb.ca/ metabolites/HMDB0006335) reporting information on record information, metabolite identification, chemical taxonomy, ontology, physical properties, chemical spectra, biological properties, normal concentrations, abnormal concentrations, associated disorders, diseases, external links, and references.

\section{Conclusion}

Alongside the increasing attention towards the standardization and need of food categorization and classification, this perspective paper gives an updated shot of the occurrence of tocols in food and existing databases as useful tool in nutrition-related studies, i.e., dietary intake assessment and exposure studies.

Although the tocols and their different homologous derivates have been consuming as additives in food and pharmaceutical industries and evaluated using advanced analysis methods during the last decade, extracting and analyzing them from complex food matrices is still timeconsuming and needs a significant quantity of organic solvents. Therefore, there is need for simple, fast, and green extraction protocols using environmentally friendly solvents. Despite the absence of any evidence of possible adverse effects following the use of tocols, caution should still be exercised in recommending the use of supplement containing them, with special attention to the recommended intake and dosage.

\section{Data Availability}

No data were used to support this study.

\section{Conflicts of Interest}

The authors declare that they have no conflicts of interest.

\section{References}

[1] D. Lu, Y. Yang, Y. Li, and C. Sun, "Analysis of tocopherols and tocotrienols in pharmaceuticals and foods: a critical review," Current Pharmaceutical Analysis, vol. 11, pp. 66-78, 2015.
[2] E. M. Bartosińska and D. Siluk, "GC-MS and LC-MS approaches for determination of tocopherols and tocotrienols in biological and food matrices," Journal of Pharmaceutical and Biomedical Analysis, vol. 127, pp. 156-169, 2016.

[3] R. K. Saini and Y.-S. Keum, "Tocopherols and tocotrienols in plants and their products: a review on methods of extraction, chromatographic separation, and detection," Food Research International, vol. 82, pp. 59-70, 2016.

[4] M. Montagnani Marelli, M. Marzagalli, F. Fontana, M. Raimondi, R. M. Moretti, and P. Limonta, "Anticancer properties of tocotrienols: a review of cellular mechanisms and molecular targets," Journal of Cellular Physiology, vol. 234, no. 2, pp. 1147-1164, 2019.

[5] K. Fukui, "Neuroprotective and anti-obesity effects of tocotrienols," Journal of Nutritional Science and Vitaminology, vol. 65, pp. 185-S187, 2019.

[6] C. L. Shen, G. Kaur, D. Wanders et al., "Annatto-extracted tocotrienols improve glucose homeostasis and bone properties in high-fat diet-induced type 2 diabetic mice by decreasing the inflammatory response," Scientific Reports, vol. 8, pp. 1-10, 2018.

[7] N. Ramanathan, E. Tan, L. J. Loh, B. S. Soh, and W. N. Yap, "Tocotrienol is a cardioprotective agent against ageing-associated cardiovascular disease and its associated morbidities," Nutrition \& Metabolism, vol. 15, no. 6, 2018.

[8] B. B. Aggarwal, C. Sundaram, S. Prasad, and R. Kannappan, "Tocotrienols, the vitamin E of the 21st century: its potential against cancer and other chronic diseases," Biochemical Pharmacology, vol. 80, no. 11, pp. 1613-1631, 2010.

[9] S. K. Wong, Y. Kamisah, N. Mohamed et al., "Potential role of tocotrienols on non-communicable diseases: a review of current evidence," Nutrients, vol. 12, no. 1, p. 259, 2020.

[10] M. Idriss, M. H. Hodroj, R. Fakhoury, and S. Rizk, "Betatocotrienol exhibits more cytotoxic effects than gammatocotrienol on breast cancer cells by promoting apoptosis via a P53-independent PI3-kinase dependent pathway," Biomolecules, vol. 10, p. 577, 2020.

[11] K. A. Zarkasi, S. Zainalabidin, J.-K. Tan, N. H. Hakimi, N. Z. Ramli, and Z. Jubri, "Tocotrienol-rich fraction modulates cardiac metabolic profile changes in isoprenaline-induced myocardial infarction rats," Sains Malaysiana, vol. 49, no. 2, pp. 357-373, 2020.

[12] L. Zhao, I. Kang, X. Fang et al., "Gamma-tocotrienol attenuates high-fat diet-induced obesity and insulin resistance by inhibiting adipose inflammation and M1 macrophage recruitment," International Journal of Obesity, vol. 39, no. 3, pp. 438-446, 2015.

[13] A. A. Qureshi, D. A. Khan, N. Silswal, S. Saleem, and N. Qureshi, "Evaluation of pharmacokinetics, and bioavailability of higher doses of tocotrienols in healthy fed humans," Journal of Clinical \& Experimental Cardiology, vol. 7, p. 434, 2016.

[14] N. Liang, S. Sun, J. Hong et al., "In vivo pharmacokinetics, biodistribution and antitumor effect of paclitaxel-loaded micelles based on $\alpha$-tocopherol succinate-modified chitosan," Drug Delivery, vol. 23, no. 8, pp. 2651-2660, 2016.

[15] J. M. Bastías-Montes, K. Monterrosa, O. Muñoz-Fariña et al., "Chemoprotective and antiobesity effects of tocols from seed oil of Maqui-berry: their antioxidative and digestive enzyme inhibition potential," Food and Chemical Toxicology, vol. 136, 2020.

[16] A. Aresta, G. Milani, M. L. Clodoveo et al., "Optimization, and comparison of different sample pre-treatments for 
simultaneous determination of vitamin $\mathrm{E}$ and vitamin $\mathrm{K}$ in vegetables," Molecules, vol. 25, 2020.

[17] K. Yamamoto, A. Kotani, and H. Hakamata, "Electrochemical detection of tocopherols in vegetable oils by supercritical fluid chromatography equipped with carbon fiber electrodes," Analytical Methods, vol. 10, no. 36, pp. 4414-4418, 2018.

[18] F. Mezni, L. Martine, M. L. Khouja, O. Berdeaux, and A. Khaldi, "Identification and quantitation of tocopherols, carotenoids and triglycerides in edible Pistacia lentiscus oil from Tunisia," Journal of Materials and Environmental Science, vol. 11, pp. 79-84, 2020.

[19] C. E. Narváez-Cuenca, M. L. Inampues-Charfuelan, A. M. Hurtado-Benavides, F. Parada-Alfonso, and J. P. Vincken, "The phenolic compounds, tocopherols, and phytosterols in the edible oil of guava (Psidium guava) seeds obtained by supercritical $\mathrm{CO}_{2}$ extraction," Journal of Food Composition and Analysis, vol. 89, Article ID 103467, 2020.

[20] I. Santana, V. N. Castelo-Branco, B. M. Guimarães et al., "Hass avocado (Persea americana Mill.) oil enriched in phenolic compounds and tocopherols by expeller-pressing the unpeeled microwave dried fruit," Food Chemistry, vol. 286, pp. 354-361, 2019.

[21] H. W. Lee, H. Zhang, X. Liang, and C. N. Ong, Simultaneous Determination of Carotenoids, Tocopherols, and Phylloquinone in 12 Brassicaceae Vegetables, LWT, London, UK, 2020.

[22] S. Niro, A. D’Agostino, A. Fratianni, L. Cinquanta, and G. Panfili, "Gluten-free alternative grains: nutritional evaluation and bioactive compounds," Foods, vol. 8, no. 6, p. 208, 2019.

[23] M. Labuschagne, N. Mkhatywa, E. Johansson, B. Wentzel, and A. Van Biljon, "The content of tocols in South African wheat; impact on nutritional benefits," Foods, vol. 6, no. 95, 2017.

[24] G. Dąbrowski, S. Czaplicki, and I. Konopka, "Fractionation of sterols, tocols and squalene in flaxseed oils under the impact of variable conditions of supercritical $\mathrm{CO}_{2}$ extraction," Journal of Food Composition and Analysis, vol. 83, Article ID 103261, 2019.

[25] J. R. Bertolín, M. Joy, P. J. Rufino-Moya, S. Lobón, and M. Blanco, "Simultaneous determination of carotenoids, tocopherols, retinol and cholesterol in ovine lyophilised samples of milk, meat, and liver and in unprocessed/raw samples of fat," Food Chemistry, vol. 257, pp. 182-188, 2018.

[26] L. Zhu, S. Yang, G. Li et al., "Simultaneous analysis of tocopherols, tocotrienols, phospholipids, $\gamma$-oryzanols and $\beta$-carotene in rice by ultra-high performance liquid chromatography coupled to a linear ion trap-orbitrap mass spectrometer," Analytical Methods, vol. 8, no. 28, pp. 5628-5637, 2016.

[27] K. Knecht, K. Sandfuchs, S. E. Kulling, and D. Bunzel, “Tocopherol and tocotrienol analysis in raw and cooked vegetables: a validated method with emphasis on sample preparation," Food Chemistry, vol. 169, pp. 20-27, 2015.

[28] Y. Wu, W. Yuan, X. Han, J. Hu, L. Yin, and Z. Lv, "Integrated analysis of fatty acid, sterol and tocopherol components of seed oils obtained from four varieties of industrial and environmental protection crops," Industrial Crops and Products, vol. 154, pp. 112-655, 2020.

[29] R. Schex, V. M. Lieb, V. M. Jimenez et al., "HPLC-DADAPCI/ESI-MS $\mathrm{n}$ analysis of carotenoids and $\alpha$-tocopherol in Costa Rican Acrocomia aculeata fruits of varying maturity stages," Food Research International, vol. 105, pp. 645-653, 2018.

[30] M. S. Diamante, C. V. Borges, I. O. Minatel et al., "Domestic cooking practices influence the carotenoid and tocopherol content in colored cauliflower," Food Chemistry, vol. 340, Article ID 127901, 2020.

[31] P. B. Pertuzatti, M. Sganzerla, A. C. Jacques, M. T. Barcia, and R. C. Zambiazi, "Carotenoids, tocopherols and ascorbic acid content in yellow passion fruit (Passiflora edulis) grown under different cultivation systems," LWT-Food Science and Technology, vol. 64, no. 1, pp. 259-263, 2015.

[32] X. Gong, N. Qi, X. Wang, J. Li, and L. Lin, “A new method for determination of $\alpha$-tocopherol in tropical fruits by ultra performance convergence chromatography with diode array detector," Food Analytical Methods, vol. 7, no. 8, pp. 1572-1576, 2014.

[33] P. Górnaś, V. Radenkovs, L. Pugajeva, A. Soliven, P. W. Needs, and P. A. Kroon, "Varied composition of tocochromanols in different types of bran: rye, wheat, oat, spelt, buckwheat, corn, and rice," International Journal of Food Properties, vol. 19, pp. 1757-1764, 2016.

[34] M. N. Moraes, G. L. Zabot, and M. A. A. Meireles, "Extraction of tocotrienols from annatto seeds by a pseudo continuously operated SFE process integrated with low-pressure solvent extraction for bixin production," The Journal of Supercritical Fluids, vol. 96, pp. 262-271, 2015.

[35] E. D. Tsochatzis and R. Tzimou-Tsitouridou, "Validated RPHPLC method for simultaneous determination of tocopherols and tocotrienols in whole grain barley using matrix solidphase dispersion," Food Analytical Methods, vol. 8, no. 2, pp. 392-400, 2014.

[36] A. Hidalgo, A. Brandolini, C. Pompei, and R. Piscozzi, "Carotenoids and tocols of einkorn wheat (Triticum monococcum ssp. monococcum L.)," Journal of Cereal Science, vol. 44, no. 2, pp. 182-193, 2006.

[37] V. F. Gowele, J. Kinabo, T. Jumbe, C. Kirschmann, J. Frank, and W. Stuetz, "Provitamin A carotenoids, tocopherols, ascorbic acid and minerals in indigenous leafy vegetables from Tanzania," Foods, vol. 8, no. 35, 2019.

[38] M. D. Nunzio, "Hazelnuts as source of bioactive compounds and health value underestimated food," Current Research in Nutrition and Food Science Journal, vol. 7, no. 1, pp. 17-28, 2019.

[39] M. Martínez, M.-J. Motilva, M.-C. López de las Hazas, M.-P. Romero, K. Vaculova, and I. A. Ludwig, "Phytochemical composition and $\beta$-glucan content of barley genotypes from two different geographic origins for human health food production," Food Chemistry, vol. 245, pp. 61-70, 2018.

[40] N. Gangopadhyay, D. K. Rai, N. P. Brunton, E. Gallagher, and S. M. Harrison, "Fatty acids, sterols and tocols in Irish barley varieties: profiling and correlation analysis," European Journal of Lipid Science and Technology, vol. 119, 2017.

[41] S. Niro, A. Fratianni, G. Panfili, L. Falasca, L. Cinquanta, and M. R. Alam, "Nutritional evaluation of fresh and dried goji berries cultivated in Italy," Italian Journal of Food Science, vol. 29, pp. 398-408, 2017.

[42] A. Ranjith, K. S. Kumar, V. V. Venugopalan, C. Arumughan, R. C. Sawhney, and V. Singh, "Fatty acids, tocols, and carotenoids in pulp oil of three sea buckthorn species (Hippophae rhamnoides, $\mathrm{H}$. salicifolia, and $\mathrm{H}$. tibetana) grown in the Indian Himalayas," Journal of the American Oil Chemists' Society, vol. 83, no. 4, pp. 359-364, 2006.

[43] M. M. Özcan, K. Ghafoor, F. Al Juhaimi, I. A. M. Ahmed, and E. E. Babiker, "Effect of cold-press and soxhlet extraction on fatty acids, tocopherols and sterol contents of the Moringa seed oils," South African Journal of Botany, vol. 124, pp. 333-337, 2019. 
[44] P. Adhikari, K. T. Hwang, M. K. Shin et al., "Tocols in caneberry seed oils," Food Chemistry, vol. 111, no. 3, pp. 687-690, 2008.

[45] P. Górnaś, A. Soliven, and D. Seglina, "Tocopherols and tocotrienols profile in seed oils recovered from industrial fruit by-products: rapid separation of $\alpha / \beta$ by RP-HPLC/FLD method," European Journal of Lipid Science and Technology, vol. 117, 2014.

[46] B. Xu, S. You, L. Zhou et al., "Simultaneous determination of free phytosterols and tocopherols in vegetable oils by an improved SPE-GC-FID method," Food Analytical Methods, vol. 13, no. 2, pp. 358-369, 2020.

[47] G. Akin, F. N. Arslan, S. N. Karuk Elmasa, and I. Yilmaz, "Cold-pressed pumpkin seed (Cucurbita pepo L.) oils from the central Anatolia region of Turkey: characterization of phytosterols, squalene, tocols, phenolic acids, carotenoids and fatty acid bioactive compounds," Grasas Y Aceites, vol. 69, no. 1, p. 232, 2018

[48] C. Yuan, Y. Xie, R. Jin et al., "Simultaneous analysis of tocopherols, phytosterols, and squalene in vegetable oils by high-performance liquid chromatography," Food Analytical Methods, vol. 10, no. 11, pp. 3716-3722, 2017.

[49] H. F. Ayyildiz, M. Topkafa, H. Kara, and S. T. H. Sherazi, "Evaluation of fatty acid composition, tocols profile, and oxidative stability of some fully refined edible oils," International Journal of Food Properties, vol. 18, no. 9, pp. 20642076, 2015.

[50] S. Pacifico, M. Scognamiglio, B. D’Abrosca, P. Monaco, and A. Fiorentino, "Tocopherols, tocotrienols, and their bioactive analogs," in Handbook of Analysis of Active Compounds in Functional Foods, CRC Press, Boca Raton, FL, USA, 2012.

[51] N. E. Craft, "Tocopherols: properties and determination," in Encyclopedia of Food and Health, Elsevier, Amsterdam, Netherlands, 2016.

[52] R. K. Saini and Y. S. Keum, "Tocopherols and tocotrienols in plants and their products: a review on methods of extraction, chromatographic separation, and detection," Food Research International, vol. 82, pp. 59-70, 2016.

[53] F. Shahidi and A. C. De Camargo, "Tocopherols and tocotrienols in common and emerging dietary sources: occurrence, applications, and health benefits," International Journal of Molecular Sciences, vol. 17, p. 1745, 2016.

[54] A. C. de Camargo, M. Franchin, and F. Shahidi, "Tocopherols and tocotrienols: sources, analytical methods, and effects in food and biological systems," Encyclopedia of Food Chemistry, pp. 561-570, 2019.

[55] H.-K. Biesalski, L. O. Dragsted, I. Elmadfa et al., "Bioactive compounds: definition and assessment of activity," Nutrition, vol. 25, no. 11-12, pp. 1202-1205, 2009.

[56] Encyclopaedia Britannica, 2020, https://www.britannica.com/ technology/database.

[57] A. Sofroniou, Relational Databases and Distributed Systems, Lulu.Com, Morrisville, CA, USA, 2018.

[58] A. Durazzo, L. D’Addezio, E. Camilli et al., "From plant compounds to botanicals and back: a current snapshot," Molecules, vol. 23, no. 8, p. 1844, 2018.

[59] A. Durazzo, M. Lucarini, and A. Santini, "Nutraceuticals in human health," Foods, vol. 9, no. 3, p. 370, 2020.

[60] P. Daliu, A. Santini, and E. Novellino, "A decade of nutraceutical patents: where are we now in 2018?" Expert Opinion on Therapeutic Patents, vol. 28, no. 12, pp. 875-882, 2018.

[61] P. Daliu, A. Santini, and E. Novellino, "From pharmaceuticals to nutraceuticals: bridging disease prevention and management," Expert Review of Clinical Pharmacology, vol. 12, no. 1, pp. 1-7, 2019.

[62] A. Santini, G. C. Tenore, and E. Novellino, "Nutraceuticals: a paradigm of proactive medicine," European Journal of Pharmaceutical Sciences, vol. 96, pp. 53-61, 2017.

[63] A. Scalbert, C. Andres-Lacueva, M. Arita et al., "Databases on food phytochemicals and their health-promoting effects," Journal of Agricultural and Food Chemistry, vol. 59, pp. 4331-4348, 2011.

[64] EFSA Panel on dietetic products, nutrition, and allergies (NDA), "Scientific opinion on dietary reference values for vitamin E as $\alpha$-tocopherol," EFSA Journal, vol. 13, p. 4149, 2015.

[65] P. M. Finglas, R. Berry, and S. Astley, "Assessing and improving the quality of food composition databases for nutrition and health applications in Europe: the contribution of EuroFIR," Advances in Nutrition, vol. 5, no. 5, pp. 608S-614S, 2014.

[66] EuroFIR-FoodEXplorer-Website: https://www.eurofir.org/ foodexplorer/login1.php 2020.

[67] M. Kiely, L. J. Black, L. J. Black et al., "EuroFIR eBASIS: application for health claims submissions and evaluations," European Journal of Clinical Nutrition, vol. 64, no. S3, pp. S101-S107, 2010.

[68] J. Plumb, S. Pigat, F. Bompola et al., "Ebasis (bioactive substances in food information systems) and bioactive intakes: major updates of the bioactive compound composition and beneficial bioeffects database and the development of a probabilistic model to assess intakes in Europe," Nutrients, vol. 9, no. 4, p. 320, 2017.

[69] eBASIS-Bioactive Substances in Food Information System. http://ebasis.eurofir.org/Default.asp.

[70] I. Dini and S. Laneri, "Nutricosmetics: a brief overview," Phytotherapy Research, vol. 33, no. 12, pp. 3054-3063, 2019.

[71] A. Santini and N. Cicero, "Development of food chemistry, natural products, and nutrition research: targeting new frontiers," Foods, vol. 9, no. 4, p. 482, 2020.

[72] A. Durazzo and M. Lucarini, "Editorial: the state of science and innovation of bioactive research and applications, health, and diseases," Frontiers in Nutrition, vol. 6, no. 178, 2019.

[73] A. Durazzo, E. Camilli, L. D’Addezio et al., "Development of dietary supplement label database in Italy: focus of FoodEx2 coding," Nutrients, vol. 12, no. 89, 2020.

[74] European Food Safety Authority, "The classification and description system FoodEx2 (revision 2)," EFSA Journal, vol. 12, 2015.

[75] M. H. Traka, J. Plumb, R. Berry, H. Pinchen, and P. M. Finglas, "Maintaining and updating food composition datasets for multiple users and novel technologies: current challenges from a UK perspective," Nutrition Bulletin, vol. 45, no. 2, pp. $230-240,2020$.

[76] Human metabolome database (HMDB) 4.0. https://hmdb.ca/. (2020).

[77] D. S. Wishart, Y. D. Feunang, A. Marcu et al., "Hmdb 4.0: the human metabolome database for 2018," Nucleic Acids Research, vol. 46, no. D1, pp. D608-D617, 2018. 